\title{
Demonstration of Continuously Seropositive Population against Borna Disease Virus in Misaki Feral Horses, a Japanese Strain: a Four-Year Follow-Up Study from 1998 to 2001
}

\author{
Yoichi INOUE ${ }^{1)}$, Kazunari YAMAGUCHI ${ }^{2)}$, Takashi SAWADA ${ }^{3)}$, Juan C. RIVERO ${ }^{1)}$ and Yoichiro HORII ${ }^{1) *}$ \\ ${ }^{1)}$ Department of Veterinary Teaching Hospital and Internal Medicine, Faculty of Agriculture, Miyazaki University, Gakuen-kibanadai, \\ Miyazaki 889-2192, ${ }^{2)}$ Blood Transfusion Service, Kumamoto University School of Medicine, Kumamoto 860-0816 and ${ }^{3)}$ Diagnostic \\ Division, Eisai Tsukuba Research Laboratories, Tsukuba 300-2635, Japan
}

(Received 13 November 2001/Accepted 28 January 2002)

ABSTRACT. Borna disease virus (BDV)-specific antibodies were monitored in Misaki feral horses annually for 4 years using an electrochemiluminescence immunoassay (ECLIA). Among 130 horses examined, 35 (26.9\%) with an ECLIA count above 1000 once or more were judged as BDV seropositive. Throughout the study period, p24 antibodies were more frequent than p40 antibodies in almost all positive animals. Among the 35 seropositive horses, the ECLIA count was consistently high in 12 cases. Eleven horses seroconverted from negative to positive and 7 underwent reversal. The count in the remaining 95 horses $(73.1 \%)$ remained low for 4 years and these animals were judged as seronegative.

KEY WORDS: antibody, Borna disease virus (BDV), Japanese feral horse.

Borna disease is a type of progressive poliomeningoencephalomyelitis that occurs naturally in horses. Borna disease virus (BDV) is the etiological agent responsible for Borna disease, and characterized as a noncytolytic, neurotropic, single-strand, negative sense RNA virus [7]. Clinical manifestations of equine Borna disease involve either simultaneous or consecutive changes in psyche, sensorium, sensitivity, motility, and the autonomic nervous system [10]. The infection can be fatal, but is often clinically invisible. BDV infection has also been identified in other vertebrate species $[1,3,4,6]$, and this virus has garnered considerable interest from the viewpoint of human psychiatric disorders $[2,5,9,11]$.

How BDV is transmitted among horses remains unclear. BDV-specific RNA has been detected in the saliva, nasal secretions and conjunctival fluid of horses with clinical signs, so BDV may be transmitted through physiological contact with these secretions of infected horses [8]. However, changes in antibody levels against BDV for long periods have not been investigated in specific individuals. Such information could be useful for specifying the time and the source of infection. We developed a novel electrochemiluminescence immunoassay (ECLIA), using recombinant BDV p24 and p40 proteins. The sensitivity and specificity is sufficient for the assay to serve as a serological screening method for measuring anti-BDV antibodies [11]. The ECLIA method has shown that moderate numbers of Misaki feral horses, a Japanese native breed are seropositive for BDV [11]. The population of Misaki feral horses has remained constant over the past few years at around 100

\footnotetext{
* Correspondence to: Horil, Y., Department of Veterinary Teaching Hospital and Internal Medicine, Faculty of Agriculture, Miyazaki University, Gakuen-kibanadai, Miyazaki 889-2192, Japan.
}

head, and all of them have been individually identified. Thus, this population was considered to be a good model with which to monitor changes in anti-BDV antibodies in individual animals. The present study annually examined the blood levels of anti-BDV antibodies in Misaki feral horses for 4 consecutive years.

Misaki feral horses live freely in the Toimisaki pasture, at the Southeastern end of Kyushu, Japan and management intervention is minimal. Once a year, usually in late June, almost of the horses are driven into a paddock and treated for internal and external parasites. From 1998 to 2001, blood samples were taken annually, concurrent with the administration. Blood samples from all captured horses were immediately centrifuged, stored at $-80^{\circ} \mathrm{C}$, and measured simultaneously soon after the final sampling.

To measure antibody against BDV, ECLIA proceeded as described [11]. Briefly, two kinds of BDV protein corresponding to full-length p24 and p40 were expressed as recombinant protein in Escherichia coli, by using the pGEX-5X-3 vector system (Pharmacia, Uppsala, Sweden), which generated the fusion protein with glutathione S-transferase (GST) and recombinant p24 and p40 proteins. Each fusion protein was bound on glutathione-Sepharose 4B (Pharmacia) and then released by factor Xa (Sigma, St. Louis, Missouri, U.S.A.), which cleaved between GST and p24 or p40 of the fusion protein. Micro beads were coated with the recombinant proteins, then suspended in bead buffer containing 10\% normal rabbit serum. The proteincoated beads were incubated with serum samples. Antibodies that adsorbed onto the micro beads were detected by electrochemically generated luminescence using the sandwich method and anti-horse IgG antibodies coupled with Ruthenium (II) tris (bipyridyl); Ru(bpy) $3^{2+}$ (IGEN International Inc., Gaithersburg, MD). The antibody level of each 
serum sample is expressed as a photocount (ECLIA count). In the first screening, a sample was considered temporarily positive if the ECLIA count was higher than the cutoff counts (1000) against mixed proteins (p24+p40) based on the mean plus 2 standard deviations (SD) of the ECLIA counts from 6 horse samples which have been confirmed as seronegative for BDV by Western blot (WB) and indirect immunofluorescence assay (IFA) in the previous study [12]. The temporarily positive sera were further examined with the following inhibition test to confirm the specificity. Each sample was incubated with PBS containing $10 \%$ normal rabbit serum and recombinant p24 and p40 proteins $(10 \mu \mathrm{g} /$ $\mathrm{ml}$ ) for $15 \mathrm{~min}$ at $37^{\circ} \mathrm{C}$. Serum samples incubated with PBS containing $10 \%$ rabbit serum alone served as the control. Thereafter, each sample was measured by ECLIA as described. A sample was declared anti-BDV antibody positive if the ECLIA count was inhibited to more than $50 \%$ of the control counts. These positive samples were further examined again by ECLIA respective for p24 and p40.

During the study period, a total of 348 serum samples was obtained from 130 horses. The annual seroprevalence of anti-BDV antibody in the Misaki horses was 19.0\%, 15.9\%, $23.3 \%$ and $24.7 \%$ in the years $1998,1999,2000$, and 2001, respectively (Table 1). In each year, p24 antibodies were more frequent than 40 antibodies in almost all positive cases.

Among 130 horses examined, anti-BDV antibody levels (ECLIA counts) of 95 animals $(73.1 \%)$ were consistently within the negative level (less than 1000 counts) for 4 years (data not shown). Table 2 shows changes in the ECLIA count in horses that were seropositive for anti-BDV antibody (over 1000 ECLIA counts) even once during the study period. Thirty-five seropositive horses were divided into 4 groups according to changes in the ECLIA count. Group 1 (12 horses) was continuously seropositive throughout the study period. Out of these, 8 horses (No. 77, 75, 65, 11, 82, 7,50 , and $36 ; 66.7 \%$ ) showed high level of ECLIA counts (over 5000 counts) at least two years during the study period. In addition, the average age of this group tended to be high (10.9 years) compared to other groups (Group2: 7.1 years, Group 3: 4.4 years). Group 2 (11 horses) seroconverted from BDV seronegative to seropositive. The age of this group tended to be rather lower than that of Group 1 with some exceptions. The rate at which the ECLIA count increased varied among individuals in this group. Seroconversion was reversed in Group 3 (7 horses), namely they changed from BDV seropositive to negative. The maximal ECLIA counts in each individual of this group was comparatively low (around 1000-2000 counts). The ECLIA count in one exception, horse No.41 was extremely high during its first year of life. However, this was considered due to maternal antibody since his mother had a similar count at the same time (No.77 Group 1). In Group 4 (5 horses), the change of ECLIA count was not clear in 4 horses since blood samples were not available until 2001. In the another case (No. 49), the horse was counted as BDV seropositive in 1998, and seroconverted to negative in the following year. However, it seroconverted to positive again in 2001.

During the study period, typical symptoms of BDV infection as described above were absent in all horses. However, 18 out of thirty-five seropositive horses $(51.2 \%: 12$ horses in Group 1, and 9 horses in Group 2 except No. 80 and No.14) were seropositive for BDV continuously. This result indicates that Misaki horses can be continuously infected with BDV without clinical manifestations. In our preliminary study, it was demonstrated that horses, which seroconverted from BDV seronegative to seropositive, had a history of cohabitation with other BDV seropositive individuals prior to seroconversion, and BDV specific-RNA was detected from the nasal secretions of these seropositive horses (unpublished data). This suggests that the horses with a consistently high anti-BDV antibody listed in Group 1 play an important role in the transmission of BDV as virus reservoirs.

The horses in Group 3 seroconverted from BDV seropositive to seronegative. Common to these horses, the maximum ECLIA counts when judged seropositive were within 1000-2000 counts, which were obviously lower than those in Group 1. We established the cutoff count as 1000 counts according to a previous study [11]. Whether this seroconversion indicates a recovery from infection or that our cutoff point (1000 count) is not appropriate for field trials, requires further clarification.

We have accurately identified experimentally infected rats and horses in a blind-test using ECLIA, which indicates that the test is reliable. In addition, the ECLIA results corresponded to those of IFA in domestic horses that were also seropositive according to sensitive and specific Western blot assays [11]. The profile of the BDV antibody of horses in this study is quite similar to those of other species, such as healthy human blood donors $(n=8, p 24$ positive $=8, p 40$ positive $=0)[11]$ and cats without clinical signs of BDV $(n=10$,

Table 1. Annual seroprevalence of anti-BDV antibody in Misaki feral horse herd from 1998 to 2001

\begin{tabular}{ccccc}
\hline & 1998 & 1999 & 2000 & 2001 \\
\hline Number of samples & 79 & 82 & 90 & 97 \\
Positive samples (\%) & $15(19.0)$ & $13(15.9)$ & $21(23.3)$ & $24(24.7)$ \\
\hline p24+p40- & 14 & 11 & 20 & 21 \\
p24-p40+ & 0 & 0 & 1 & 0 \\
p24+p40+ & 1 & 2 & 0 & 3 \\
\hline
\end{tabular}


Table 2. The changes of ECLIA count in BDV seropositive horses from 1998 to 2001

\begin{tabular}{|c|c|c|c|c|c|c|}
\hline ID number & & Age in 2001 & & ECLIA counts & $\begin{array}{l}\mathrm{p} 24+\mathrm{p} 40 \\
(\mathrm{p} 24, \mathrm{p} 40)\end{array}$ & \\
\hline of horse & Sex & (years) & 1998 & 1999 & 2000 & 2001 \\
\hline \multicolumn{7}{|c|}{ 1. Continuously positive (12 cases) } \\
\hline 77 & Female & 7 & $\begin{array}{c}46734 \\
(80185,2747)\end{array}$ & $\begin{array}{c}30188 \\
(60601,135)\end{array}$ & $\begin{array}{c}28834 \\
(46168,193)\end{array}$ & $\begin{array}{c}23047 \\
(45094,266)\end{array}$ \\
\hline 75 & Male & 16 & $\begin{array}{c}19648 \\
(27704,561)\end{array}$ & $\begin{array}{c}10323 \\
(18881,1908)\end{array}$ & $\begin{array}{c}12544 \\
(24227,588)\end{array}$ & $\begin{array}{c}13351 \\
(27503,662)\end{array}$ \\
\hline 65 & Female & 9 & $\begin{array}{c}9614 \\
(15713,345)\end{array}$ & $\begin{array}{c}10317 \\
(21671,354)\end{array}$ & $\begin{array}{c}14289 \\
(23900,589)\end{array}$ & $\begin{array}{c}12097 \\
(24594,652)\end{array}$ \\
\hline 11 & Male & 9 & $\begin{array}{c}9124 \\
(14457,573)\end{array}$ & $\begin{array}{c}9169 \\
(21720,280)\end{array}$ & $\begin{array}{c}19569 \\
(35258,722)\end{array}$ & $\begin{array}{c}13441 \\
(28682,665)\end{array}$ \\
\hline 82 & Female & 7 & $\begin{array}{c}2930 \\
(5115,378)\end{array}$ & $\begin{array}{c}2700 \\
(6405,331)\end{array}$ & $\begin{array}{c}7580 \\
(12434,663)\end{array}$ & $\begin{array}{c}7736 \\
(16472,465)\end{array}$ \\
\hline 7 & Male & 9 & $\begin{array}{c}7190 \\
(12415,391)\end{array}$ & $\begin{array}{c}5090 \\
(10224,519)\end{array}$ & ND & $\begin{array}{c}6158 \\
(11316,221)\end{array}$ \\
\hline 50 & Female & 13 & $\begin{array}{c}5960 \\
(10026,114)\end{array}$ & $\begin{array}{c}3136 \\
(7531,112)\end{array}$ & $\begin{array}{c}8933 \\
(16380,199)\end{array}$ & ND \\
\hline 22 & Female & 14 & $\begin{array}{c}2689 \\
(4831,483)\end{array}$ & ND & $\begin{array}{c}3625 \\
(7699,992)\end{array}$ & $\begin{array}{c}1954 \\
(3908,777)\end{array}$ \\
\hline 99 & Male & 6 & $\begin{array}{c}1374 \\
(1463,994)\end{array}$ & ND & $\begin{array}{c}2512 \\
(2505,656)\end{array}$ & $\begin{array}{c}1910 \\
(2890,667)\end{array}$ \\
\hline 36 & Male & 12 & $\begin{array}{c}14710 \\
(25856,254)\end{array}$ & ND & $\begin{array}{c}7462 \\
(14596,790)\end{array}$ & ND \\
\hline 79 & Male & 22 & $\begin{array}{c}1799 \\
(2796,634)\end{array}$ & ND & ND & $\begin{array}{c}2197 \\
(4259,514)\end{array}$ \\
\hline 64 & Male & 7 & $\begin{array}{c}1642 \\
(2509,188)\end{array}$ & $\begin{array}{c}8340 \\
(10740,2839)\end{array}$ & ND & ND \\
\hline \multicolumn{7}{|c|}{ 2. Negative to positive ( 11 cases) } \\
\hline 90 & Male & 3 & 31 & ND & ND & $\begin{array}{c}22504 \\
(50884,2800)\end{array}$ \\
\hline 9940 & Male & 2 & ND & 486 & $\begin{array}{c}9971 \\
(16220,72)\end{array}$ & $\begin{array}{c}13158 \\
(22341,215)\end{array}$ \\
\hline 9902 & Male & 2 & ND & 145 & $\begin{array}{c}4420 \\
(6699,223)\end{array}$ & $\begin{array}{c}1997 \\
(4102,203)\end{array}$ \\
\hline 76 & Female & 3 & 75 & $\begin{array}{c}1558 \\
(2811,113)\end{array}$ & $\begin{array}{c}3177 \\
(4761,100)\end{array}$ & $\begin{array}{c}1408 \\
(2916,122)\end{array}$ \\
\hline 52 & Female & 12 & 724 & 875 & $\begin{array}{c}2226 \\
(1821,755)\end{array}$ & $\begin{array}{c}1465 \\
(2831,655)\end{array}$ \\
\hline 30 & Female & 12 & 276 & 938 & $\begin{array}{c}1580 \\
(1170,464)\end{array}$ & $\begin{array}{c}1809 \\
(3221,432)\end{array}$ \\
\hline 32 & Female & 19 & ND & 898 & $\begin{array}{c}2162 \\
(2059,514)\end{array}$ & $\begin{array}{c}1672 \\
(2895,321)\end{array}$ \\
\hline 12 & Male & 11 & 623 & 994 & $\begin{array}{c}2760 \\
(3170,814)\end{array}$ & $\begin{array}{c}3996 \\
(4992,677)\end{array}$ \\
\hline 99003 & Female & 2 & ND & 412 & $\begin{array}{c}2330 \\
(4612,100)\end{array}$ & $\begin{array}{c}4478 \\
(5230,234)\end{array}$ \\
\hline 80 & Female & 7 & 187 & 812 & $\begin{array}{c}2851 \\
(1975,357)\end{array}$ & ND \\
\hline 14 & Female & 5 & 588 & 763 & $\begin{array}{c}2098 \\
(3023,492)\end{array}$ & ND \\
\hline
\end{tabular}

p24 positive $=10, \mathrm{p} 40$ positive $=3$ ) [4], all of which harbored p24 antibodies. This may be a common feature of sub-clinical BDV infection in mammalians.

BDV infection in horses has been reported in various countries [10]. In the previous study, it was suggested that the major mode of BDV transmission among animals is horizontal transmission [8]. However, direct evidence has not been revealed yet. The consecutive monitoring of horses with high levels of anti-BDV antibody such as those in Group 1 together with observations of their social behavior, might help to further understanding of BDV transmission in horses.

ACKNOWLEDGEMENTS. This work was supported in 
Table 2. Continued.

\begin{tabular}{|c|c|c|c|c|c|c|}
\hline ID number & & Age in 2001 & & ECLIA counts & $\begin{array}{l}\mathrm{p} 24+\mathrm{p} 40 \\
(\mathrm{p} 24, \mathrm{p} 40)\end{array}$ & \\
\hline of horse & Sex & (years) & 1998 & 1999 & 2000 & 2001 \\
\hline \multicolumn{7}{|c|}{ 3. Positive to negative ( 7 cases) } \\
\hline 26 & Female & 8 & $\begin{array}{c}1924 \\
(2934,421)\end{array}$ & 589 & 512 & 608 \\
\hline 46 & Male & 6 & 252 & $\begin{array}{c}1156 \\
(1936,335)\end{array}$ & 592 & 840 \\
\hline 21 & Male & 3 & 361 & $\begin{array}{c}1574 \\
(3442,97)\end{array}$ & 594 & 877 \\
\hline 84 & Female & 6 & $\begin{array}{c}1521 \\
(2390,166)\end{array}$ & $\begin{array}{c}1570 \\
(2373,471)\end{array}$ & 918 & 595 \\
\hline 96 & Female & 3 & 108 & $\begin{array}{c}1804 \\
(3286,374)\end{array}$ & 511 & ND \\
\hline 9961 & Male & 2 & ND & ND & $\begin{array}{c}1963 \\
(523,2388)\end{array}$ & 664 \\
\hline 41 & Male & 3 & $\begin{array}{c}46270 \\
(69733,690)\end{array}$ & 578 & 465 & 533 \\
\hline \multicolumn{7}{|c|}{ 4. Other cases ( 5 cases) } \\
\hline 0177F & Female & 0 & ND & ND & ND & $\begin{array}{c}3259 \\
(6877,57)\end{array}$ \\
\hline 33 & Male & 5 & ND & ND & ND & $\begin{array}{c}7574 \\
(16530,1191)\end{array}$ \\
\hline 88 & Female & 6 & ND & ND & ND & $\begin{array}{c}7735 \\
(17905,274)\end{array}$ \\
\hline $93 \mathrm{G}$ & Male & 22 & ND & ND & ND & $\begin{array}{c}4834 \\
(8942,2028)\end{array}$ \\
\hline 49 & Female & 19 & $\begin{array}{c}1150 \\
(1539,125)\end{array}$ & 838 & 962 & $\begin{array}{c}2310 \\
(4861,293)\end{array}$ \\
\hline
\end{tabular}

$\mathrm{ND}=$ no data.

part by The Inui Memorial Trust for Research on Animal Science.

\section{REFERENCES}

1. Bode, L., Durrwald, R. and Ludwig, H. 1994. Vet. Rec. 135: 283-284.

2. Fu, F., Amsterdam, J. D., Kao, M., Shankar, V., Koprowski, H. and Dietzshold, B. 1993. J. Affect. Disord. 27: 61-68.

3. Hagiwara, K., Kawamoto, S., Takahashi, H., Nakamura, Y., Nakaya, T., Hiramune, T., Ishihara, C. and Ikuta, K. 1997. Clin. Diagn. Lab. Immunol. 4: 339-344.

4. Horii, Y., Garcia, J. N. P., Noviana, D., Kono, F., Sawada, T., Naraki, T. and Yamaguchi, K. 2001. J. Vet. Med. Sci. 63: 921923.

5. Lipkin, W. I., Schneemann, A. and Solbrig, M. V. 1995. Trends. Microbiol. 3: 64-69.
6. Narayan, O., Herzog, S., Frese, K., Scheefers, H. and Rott, R. 1983. Science 220: 1401-1403.

7. Pringle, C. R. 1997. Arch.Virol. 142: 2321-2326.

8. Richt, J. A., Herzog, S., Haberzettl, K. and Rott, R. 1993. Med. Microbiol. Immunol. 182: 293-304.

9. Richt, J. A., Pfeuffer, I., Christ, M., Frese, K., Bechter, K. and Herzog, S. 1997. Emerg. Infect. Dis. 3: 343-352.

10. Richt, J. A., Grabner, A. and Herzog, S. 2000. Emerg. Infect. Dis. 16: 579-595.

11. Yamaguchi, K., Sawada, T., Naraki, T., Igata-Yi, R., Shiraki, H., Horii, Y., Ishii, T., Ikeda, K., Asou, N., Okabe, H., Mochizuki, M., Takahashi, K., Yamada, S., Kubo, K., Yashiki, S., Waltrip, R. W. 2nd. and Carbone, K. M. 1999. Clin. Diagn. Lab. Immunol. 6: 696-700.

12. Yamaguchi, K., Sawada, T., Yamane, S., Haga, S., Ikeda, K., Igata-Yi, R., Yoshiki, K., Matsuoka, M., Okabe, H., Horii, Y., Nawa, Y., Waltrip, R. W. 2nd. and Carbone, K. M. 2001. Ann. Clin. Biochem. 38: 348-355. 